\title{
Redactioneel
}

\section{Het vertrouwensbeginsel en de afstand tussen Kneuterdijk en Korte Voorhout}

Prof. mr. G.A. (Gerrit) van der Veen*

\section{Inleiding}

Op 29 mei 2019 deed de Afdeling bestuursrechtspraak een uitspraak die diverse pennen in beweging heeft gebracht. ${ }^{1}$ Het gemeentebestuur van Amsterdam had zich net voor de kerst van 2016 voorgenomen om handhavend op te treden tegen een dakopbouw die tot dan toe zo'n kwart eeuw zonder al te veel zorgen, maar ook zonder toereikende vergunning, in gebruik was geweest. Het bleek dat in plaats van die vergunning wel van begin af aan overleg met gemeentelijke ambtenaren over de bewuste opbouw was gevoerd. Verder bleek onder meer dat ambtenaren de toenmalige eigenaar welbewust en gemotiveerd hadden afgeraden om een aanvraag voor een vergunning in te dienen, onder meer omdat de richtlijnen en bevoegdheden van Bouw- en woningtoezicht in Amsterdam aangepast zouden worden naar stadsdeel.

Aan de uitspraak ging een zeer lezenswaardige conclusie van A-G Wattel vooraf. Zijn schets van de voorgeschiedenis doet vermoeden dat de toenmalige eigenaren ook wel wisten dat eigenlijk een vergunning vereist was. $\mathrm{Zij}$ hadden daarop namelijk zelf een aantal malen bij de ambtenaren aangedrongen, maar kennelijk tevergeefs. Ook overigens was de opbouw bij gemeentelijke functionarissen bekend, en werd kennelijk nooit een punt gemaakt van de ontbrekende vergunning. Zou men als advocaat in een zaak een beroep op het vertrouwensbe-

* Prof. mr. G.A. van der Veen is advocaat bij AKD te Rotterdam, bijzonder hoogleraar milieurecht aan de Rijksuniversiteit Groningen en lid van de redactie van TO

1. ABRvS 29 mei 2019, ECLI:NL:RVS:2019:1694. ginsel willen doen, dan zou men likkebaardend kijken naar de veelheid aan uitlatingen die hier gedaan waren en alle gedragingen die zich hier hadden afgespeeld. Die uitlatingen en gedragingen werden in de procedure die tot de uitspraak leidde, ook niet in twijfel getrokken.

Alleen, geen van de uitlatingen en gedragingen was van het college zelf afkomstig. Dat was problematisch. De regel was immers dat gerechtvaardigd vertrouwen eigenlijk alleen door het bevoegde orgaan kan worden gewekt. Auteur dezes zal niet zeggen dat hij nog wakker ligt van ABRvS 11 januari 2006, ${ }^{2}$ maar dat was in ieder geval een vrij harde toepassing van die regel. Incidenteel werd wel getornd aan de regel, zoals in de kwestieuze zaak van de Overbetuwse paardenbak. ${ }^{3}$ Daar valt echter te constateren dat de bewuste gemeente vergeven was van de illegale paardenbakken. Men zou daar kunnen zeggen dat handhaving tegen één paardenbak de uitzondering op de gemeentelijke praktijk zou vormen, en dat ook een beroep op het gelijkheidsbeginsel ver had kunnen komen.

Wat van het incident 'paardenbak' verder ook zij, de Afdeling kwam in de uitspraak van 29 mei 2019 tot een nieuwe invulling van het vertrouwensbeginsel. Bij de beoordeling van een beroep op het vertrouwensbeginsel moeten, aldus thans de Afdeling, drie stappen worden doorlopen. De eerste is de juridische kwalificatie van de uitlating en/of gedraging waarop de betrokkene zich beroept. Doorgaans zullen de uitlating en/of gedraging door een ambtenaar worden gedaan of worden verricht, maar dit kan ook gebeuren door anderen, bijvoorbeeld een wethouder of derden die door het bestuursorgaan worden ingeschakeld. Kunnen die uitlating en/of gedraging worden gekwalificeerd als een toezegging? Bij de 
tweede stap moet de vraag worden beantwoord of die toezegging aan het bevoegde bestuursorgaan kan worden toegerekend. Indien beide vragen bevestigend worden beantwoord, en er dus een geslaagd beroep op het vertrouwensbeginsel kan worden gedaan, volgt de derde stap. In het kader van die derde stap zal de vraag moeten worden beantwoord wat de betekenis van het gewekte vertrouwen is bij de uitoefening van de betreffende bevoegdheid, aldus de Afdeling in de uitspraak van 29 mei 2019.

De kern van de vernieuwing zit in de tweede stap. Daarbij maakt de Afdeling duidelijk dat zij voortaan ook in gevallen waarin niet uitdrukkelijk is aangegeven dat de toezegging namens het bevoegde orgaan wordt gedaan, minder de nadruk zal leggen op de precieze bevoegdheidsverdeling. Ook in die gevallen kan een toezegging worden toegerekend aan het bevoegde orgaan, indien de betrokkene op goede gronden mocht veronderstellen dat degene die de toezegging heeft gedaan de opvatting van het bevoegde orgaan vertolkte.

Ten aanzien van die 'goede gronden' geeft de Afdeling dan nog een toelichting. Indien een wethouder met een bepaalde portefeuille de indruk wekt dat hij de opvatting van het college vertolkt en op het terrein van zijn portefeuille toezeggingen doet, terwijl het voor de betrokkene niet eenvoudig kenbaar is dat deze wethouder daartoe niet bevoegd is en niemand hem daarop wijst, kan het college zich niet met succes beroepen op de onbevoegdheid van de wethouder om een dergelijke toezegging te doen, aldus de Afdeling. Met andere woorden, de bestuurlijke bevoegdheidstoedeling en het ontbreken van bevoegdheden bij (bijvoorbeeld) wethouders zijn niet langer de zorg van de burger. Onder verwijzing naar Ackermans-Wijn kan de wethouder zelf dus 'veelbelovend' worden. ${ }^{4}$ Dat was eerder in beginsel niet mogelijk.

De nieuwe koers van de Afdeling staat haaks op de koers die de Hoge Raad tot dusverre aanhoudt. Volgens duidelijke arresten als HR 26 juni $2015^{5}$ komt in het stelsel van de Gemeentewet groot gewicht toe aan de bevoegdheidsverdeling tussen het college van $B \& W$ en de gemeenteraad. De raad heeft een autonome positie, en grote terughoudendheid moet worden betracht bij het aannemen van gebondenheid van een gemeente zonder instemming van de raad in gevallen waar de raad een formele positie in het besluitvormingsproces inneemt. Dat geldt ook in gevallen waarin die formele positie wordt ontleend aan een contractueel voorbehoud van instemming (...). De zelfstandige beslissingsvrijheid van de raad brengt mee dat een wederpartij niet erop mag vertrouwen dat handelingen van het college de instemming van de raad hebben indien dat vertrouwen niet mede wordt ontleend aan toedoen van de raad zelf, aldus de Hoge Raad. Anders dan de Afdeling thans vindt, vindt de Hoge Raad dus dat een partij die (zakelijk) met de gemeente omgaat, van de ins en outs van de bestuurlijke bevoegdheidsverdeling op de hoogte moet zijn.

Een en ander geldt bij de Hoge Raad (uiteraard) ook voor andere bestuurslagen en ook voor vorderingen die op de onrechtmatige daad zijn gebaseerd. Uit de Provinciewet vloeit voort dat de gedeputeerden zonder delegatie of goedkeuring achteraf door provinciale staten niet bevoegd waren de provincie door de onderhavige toezegging te binden. Er moet grote terughoudendheid worden betracht bij het aannemen van gebondenheid van (een gemeente dan wel) een provincie zonder instemming van het ter zake volgens de wet bevoegde orgaan, in dit geval provinciale staten, aldus HR 24 juni $2016 .^{6}$

Bij de Hoge Raad is het uitgangspunt dus (of: dus nog?) dat het bestuursorgaan zelf de hand moet hebben in gedragingen die kunnen leiden tot een gerechtvaardigd vertrouwen dat anderen dan het bevoegd gezag kunnen binden. De Afdeling wijkt daar thans uitdrukkelijk van af met de constatering dat de betrokken onbevoegde zichzelf kan verheffen en zo relevante rechtsgevolgen kan bewerkstelligen. We zullen moeten bezien of de Afdelingsjurisprudentie alleen relevantie houdt voor de eenzijdige bestuurshandelingen (van besluiten in de zin van art. 1:3 Algemene wet bestuursrecht), of dat de door de Hoge Raad in de contractuele sfeer streng uitgeschreven bestuurlijke bevoegdheidsverdeling nu ook gaat schuiven. Ik zou me kunnen voorstellen dat degenen die met overheden willen contracteren, zich nog steeds goed moeten verdiepen in de bestuurlijke bevoegdheidsverdeling. Dat zou de rechtseenheid overigens niet direct bevorderen.

\section{De inhoud van deze aflevering van het Tijdschrift voor Omgevingsrecht}

In hun artikel 'De uitwerking van de Dienstenrichtlijn in het Nederlandse stelsel van ruimtelijke ordening' gaan Marleen Botman en Daniëlle Roelands-Fransen in op recente jurisprudentie van met name de Afdeling bestuursrechtspraak van de Raad van State over de vraag of de haar voorgelegde ruimtelijke voorschriften die economische activiteiten reguleren in overeenstemming zijn met de regels van het vrij verkeer, meer specifiek de vrijheid van vestiging en de Europese Dienstenrichtlijn 2006/123/EG. Zij gaan met name in op de vraag in hoeverre ruimtelijke voorschriften de vestiging van detailhandel kunnen reguleren door middel van brancheringsregelingen (de zaak Appingedam had namelijk betrekking op een brancheringsregeling voor de vestiging van detailhandel). Aan het slot van hun artikel geven zij een doorkijkje naar de toets aan de 
Dienstenrichtlijn onder het systeem van de Omgevingswet.

Jan Reinier van Angeren vraagt in zijn artikel aandacht voor een meer integrale benadering van het omgevingsrecht en de mobiliteit. De auteur onderzoekt wat de rol is van mobiliteitsvraagstukken bij gemeentelijke bestemmingsplannen en concludeert aan de hand van de bespreking van de jurisprudentie over de toepassing van de CROW-publicatie 317 bij de vraag hoeveel autoverkeer een ruimtelijke ontwikkeling genereert, dat een integrale beoordeling van de gevolgen van een ruimtelijke ontwikkeling op de mobiliteitsvraag en -behoefte ontbreekt. In zijn artikel kijkt Van Angeren ook naar de (beperkte) rol van mobiliteit in de Omgevingswet en onderzoekt hij wat de verhouding is tussen de Omgevingswet en de Wet Infrastructuurfonds.

In hun bijdrage over de planologische kernbeslissing Ruimte voor de Rivier (PKB RvR) geven Marlon Boeve, Berthy van den Broek, Frank Groothuijse, Andrea Keessen en Marleen van Rijswick antwoord op de vraag welke juridisch-bestuurlijke lessen voor toekomstige grootschalige infrastructurele overheidsprojecten getrokken kunnen worden. De PKB RvR is - anders dan vele andere door de overheid uitgevoerde grootschalige en ingrijpende infrastructurele projecten - vrijwel tijdig met het bereiken van de voorgenomen doelstellingen en binnen het oorspronkelijk budget uitgevoerd. Onderzocht is welke juridisch-bestuurlijke aspecten daaraan hebben bijgedragen. Auteurs gaan in op een zestal aspecten: decentralisatie en interbestuurlijke vormgeving, integraliteit van besluitvorming, participatie van burgers en marktpartijen, projectorganisatie, snelheid en coördinatie van besluitvorming, flexibiliteit in besluitvorming en kwaliteit van besluitvorming.

De lessen zijn in de eerste plaats van belang voor toekomstige infrastructurele projecten ten behoeve van het overstromingsrisicobeheer, maar kunnen ook van belang zijn voor andere grote (infrastructurele) projecten, die bijvoorbeeld moeten worden uitgevoerd in het kader van de energietransitie, zoals de aanleg van windparken en zonnevelden en bijbehorende kabels en leidingen, of in het kader van de mobiliteit, zoals de aanleg en aanpassing van (spoor)wegen. 